\title{
Research on Management of homestead land in new urbanization progress
}

\author{
FU Weiqiang \\ College of Economics and Management \\ China Jiliang University \\ Hangzhou, China \\ 1425287633@qq.com \\ TANG Xiaoling \\ College of Economics and Management \\ China Jiliang University \\ Hangzhou, China \\ www520tang.com@qq.com
}

\author{
LIU Jiapeng \\ College of Economics and Management \\ China Jiliang University \\ Hangzhou, China \\ jpliu@cjlu.edu.cn \\ YI Ronghua \\ College of Economics and Management \\ China Jiliang University \\ Hangzhou, China \\ yirh@cjlu.edu.cn
}

\begin{abstract}
In recent years, with the rapid development of China's economy and the city to speed up the process, the management of land use is particularly important. This article through to the family living area changes before and after the transformation of the comparative analysis, puts forward some problems in the process of new rural construction, and combined with some policy about homestead puts forward some suggestions for the reform of housing land management. These suggestions include that changing land use system and the implementation of land paid use; scientific development village planning and effective implementation of land management; science and the implementation of land use regulation, the full implementation of housing land use right registration..
\end{abstract}

Keywords-new urbanization;new rural construction; homestead; suggestions; Solutions

\section{INTRODUCTION}

In recent years, with the rapid development of China's economy and the city to speed up the process, the management of land use is particularly important. rural homestead is an important part of rural land, the management of homestead cannot be ignored. Some scholars have done a lot of research in the construction of new countryside homestead question. Liu Yaguang (2011) reviewed on China's rural homestead land issues[1]. Zhang Zhenyong (2013) reviews the evolution process of Chinese rural homestead system [2]. Zhou Liqun, Zhang Hongxing (2011) research exchange of rural land institutional change process from the "Homestead" to "ticket" [3].

Due to historical reasons, Chinese homestead system has some problems. Diao Qihuai(2011) pointed out that the rural homestead right of use system problems and proposed the reform direction[4]. Wang Liuyan (2011) makes an analysis of the conflict on the use right of homestead and house inheritance [5]. Cao Qiang (2012) studies the legal problems of rural homestead circulation [6].
The transfer of homestead and exit also has many problems to be researched. Dong Hong (2011) study the transfer market mechanism of rural land use right [7]. Wu Mingfa (2012) studied on the transfer mechanism of land use right[8]. Xue Fengrui (2014) discussion on rural land occupation and the innovation of transfer system[9]. Chen Rongqing, Zhang Ming, Chen Hongfei (2011) makes empirical analysis on rural homestead circulation from the perspective of farmers[10]. Song Jinyun (2014) studies the problems in homestead exit mechanism of citizenization of migrant workers[11]. Dai Yanyan (2012) is devoted to the study of Shanghai Rural Homestead exit mechanism [12].

He Changhong(2011) suggested on homestead management problems [13]. Shen Peng (2012) put forward the idea of improvement of rural homestead management [14]. In this paper, on the basis of the above research, through to the transformation of the family living area changes before and after the comparative analysis, put forward some encountered in the process of new rural construction, and with some policy advice for the homestead in the reconstruction process management.

\section{COMPARATIVE ANALYSIS OF FAMILY LIVING AREA BEFORE AND AFTER THE URBANIZATION}

We through the study of the random sampling about demolition area in zhejiang province is a family of farmers the demolition area changes of the living area.

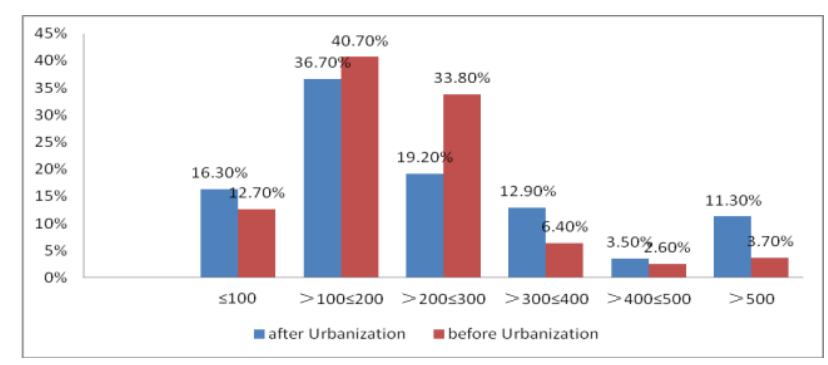

Figure 1. The distribution of building area 


\begin{tabular}{ccc} 
Building area $\left(\mathbf{m}^{\mathbf{2}}\right)$ & Frequency & Percentage \\
\hline$\leqslant 100$ & 58 & $12.7 \%$ \\
$>100 \leqslant 200$ & 185 & $40.7 \%$ \\
$>200 \leqslant 300$ & 154 & $33.8 \%$ \\
$>300 \leqslant 400$ & 29 & $6.4 \%$ \\
$>400 \leqslant 500$ & 12 & $2.6 \%$ \\
$>500$ & 17 & $3.7 \%$ \\
Effective sample & 455 & \\
\hline Deficiency & 36 & $100 \%$ \\
Amount to & 491 & \\
Mean valu & \multicolumn{3}{|}{221.4} \\
Median & \multicolumn{3}{|}{200} \\
Mode & \multicolumn{2}{|}{285} \\
\hline
\end{tabular}

TABLE II. CURRENTLY HAS BUILDING AREA

\begin{tabular}{|c|c|c|}
\hline Building area $\left(\mathrm{m}^{2}\right)$ & Frequency & Percentage \\
\hline 100 & 78 & $16.3 \%$ \\
\hline$>100 \leqslant 200$ & 176 & $36.7 \%$ \\
\hline$>200 \leqslant 300$ & 92 & 19. $2 \%$ \\
\hline$>300 \leqslant 400$ & 62 & $12.9 \%$ \\
\hline$>400 \leqslant 500$ & 17 & $3.5 \%$ \\
\hline$>500$ & 54 & $11.3 \%$ \\
\hline Effective sample & 479 & \\
\hline Deficiency & 12 & \\
\hline Amount to & 491 & $100 \%$ \\
\hline Mean valu & \multicolumn{2}{|c|}{258.6} \\
\hline Median & \multicolumn{2}{|c|}{200} \\
\hline Mode & \multicolumn{2}{|c|}{300} \\
\hline
\end{tabular}

\section{THE HOMESTEAD MANAGEMENT, PROBLEMS IN NEW RURAL CONSTRUCTION}

\section{A. The homestead management confusion, lack of unified planning of residential}

With the continuous development of economic level, people require for the standard of living is getting higher and higher, many farmers began to build the house, began to improve their quality of life. But farmers land waste phenomenon is serious, not unified planning basically, where is good where built in location selection, most in their land plots, or more convenient traffic on both sides of the road, some of the outskirts of the village space, causing the layout of rural settlements scattered, has not formed the centralized distribution situation and the

formation of the extension and expansion the homestead. New house sales perplexing, extremely confusing, and the occupation of cultivated land is more, poor quality of environment. Most of the village construction lack of overall planning of scientific and rational, layout, scale, spatial structure of villages are lack of scientific, resulting in a serious waste of land. In recent years, more and more attention to planning problems, many city also began to city planning. However, in the vast rural areas, the traditional mode of housing is still prevailing, planning and construction of life supporting facilities of the concept is still not accepted by the. Although in the government's request to many towns have developed some simple town planning, but most of these programming knowledge is not in place, the concept of aging, lack of considering the overall, long-term, and some even just to cope with the job. Because of the lack of the necessary investigations in the formulation of planning, thus failing to determine reasonable size towns, the planning is not implemented, and even some planning did not consider the basic living facilities. Coupled with the examination and approval management land always exist such problems, many farmers homestead without legal approval procedures, the majority of farmers free housing, and this has caused economic income and material conditions in the vast rural area increased rapidly at the same time, the rural living environment but not dirty chaos phenomenon. Not only that, many homestead base idle, village scale is gradually expanding, and gradually occupied the villages surrounding farmland, all of these cause a waste of land resources and low utilization rate[15].

\section{B. The homestead circulation in a single, trade disputes}

The nature of rural homestead belongs to the rural collective ownership, according to the provisions of the laws and regulations of our country, the farmers of their lawfully obtained land only the right to use, there is no right of disposal, not to transfer. However, to have been built in the rural homestead on the residential whether it can be transferred, the current laws and regulations have no clear provisions, but there is no clear rules allow the transfer of. "Land management law" sixty-second article only stipulates: "the villagers sell, rental housing, and then apply for homestead, shall not be approved". It can be seen in the countryside homestead right of use circulation problems, the state take is mandatory, basically is the free transfer ban homestead. Li Manzhi scholars in "transfer" the right to use the property law under the homestead in the article, the right to use the transfer of homestead property law although made specific provision, but the transaction is narrow, is not conducive to the value of play[16], must request against the development of the socialist market economy. With the advent of the sale of rural housing, land transfer is inevitable, but transfer behavior of these sites are not subject to the existing laws and regulations, which belongs to the private circulation. Once the two sides of contradictions and disputes, the court can only be called on both sides to resolve the dispute through consultation, the right cannot be protected effectively. But the "covert operation", arbitrary pricing 
transfer behavior that belonged to the village collective all land revenue serious erosion.

\section{Regulations are not perfect, the relevant provisions of lag}

China's current laws and regulations about the number of peasant homestead management less, and the effectiveness of low level, there are not a country to adjust the housing and land in terms of civil law, land management depends on the adjustment of.1993 files and local policy norms, the State Council promulgated the "Regulations on the management of village and town planning and construction of" although the provisions building procedures and approval authority to a great extent, but also solve the problem of land circulation and the dispute did not make provisions; to strengthen the rural homestead management, the State Council in 1990 January, "although the administration of the former state land on the strengthening of the rural homestead management work instructions", for examination and approval management, land planning and management, land management and development of land paid use of the pilot of a clearly defined, but the homestead and registration certification also did not make provisions. In 2004 November the Ministry of land and resources issued "on the strengthening of the rural homestead management advice". The paper puts forward the guideline of the national land management from the land planning, land planning and management, application procedures, administrative measures and rural land intensive utilization, but to the homestead right of use circulation of restrictive regulations, and prohibited the purchase of urban residents in rural villages, is strictly prohibited for the issuance of land use for urban residents to purchase and illegal construction in the rural residential. The prohibitive provisions whether conforms to our country city and economic development requirements, compliance with the law of social development of integration of urban and rural areas, is still to be explored; and this provision to the opinions of the departments promulgated forms, low legal effect. Compared with the city real estate management legislation is more complete, the lag of rural homestead legislation, not only the existence of a legal vacuum, but the content is superficial [17].

\section{RELEVANT POLICIES ON LAND MANAGEMENT}

\section{A. to strengthen the planning control land use planning of rural residential construction.}

According to the need of new rural construction, the provincial administrative department of land and resources to co-ordinate the arrangements for land and resources, and guide city, county administrative departments, combined with a new round of township (town) revision of overall land use planning, land use planning, organization, reported to the people's government at the county level for approval. In the land use planning to determine the overall urban construction land use expansion planning within the boundaries of the village, to link up with the town planning, reasonable delineation of farmers housing land; in the overall planning of land use to determine the town construction expands the boundary outside the village, land and resources management departments at the county level to ascertain the land use situation and with the basic requirements, to the township (town) the overall land use planning and village land use planning control, organize the compilation of village homestead situation map, residential construction land planning and land demand forecast ten year plan table (i.e. "two charts and a table"), to establish and perfect the land examination and approval system, publication, guiding farmers housing construction specification according to the planning, planned, orderly.

\section{B. the strict standards and norms, improve land management system}

Strictly homestead area standards. The homestead is to obtain the farmers in accordance with the law for collective construction the construction of residential and ancillary facilities for life, "a house" refers to the rural residents who can only apply for one of the fund provisions of the standard size. To give full play to the role of village autonomous organization according to the management of land function. Strengthen the homestead application with supervision. The farmer new applications for housing land, must be controlled to within the required standards. The farmer new applications for housing land, must be controlled to within the required standards.

The rational allocation of land. Determine the overall plan for land use of urban construction expansion within the boundaries of the suburb, rural residents of suburban land, in principle no longer single dispersed homestead allocation, encourage farmers to focus on the building of new homes. Land use planning to determine the overall urban construction extended boundary outside the village, to strictly enforce the one family can only apply for one in line with the policy provisions of the standard size of the homestead. Better economic conditions, land resources supply and demand contradiction prominent place, allowing the village self-government organizations to apply for new homestead household to carry out land paid use of pilot. The pilot program by the village autonomous organization by the villagers meeting to discuss the proposed, the implementation of approved by the city, county land and resources management departments audit report to the provincial land and resources management departments, accept the supervision and management.

Strengthening rural land registration certification and file management. All localities should according to the relevant provisions, to accelerate the land registration certification, properly handle the land dispute. To find out the land base, master land use status, and register, establish and perfect the homestead records and management system, to change a, register a. We must actively establish a dynamic management information system of rural land, rural residential land use, application, examination and approval, and the information communicated up and down, dynamic management, public inquiry. 


\section{ADVICES ON HOMESTEAD MANAGEMENT}

\section{A. changes in land use system, implementation of compensation for the use of land}

At present, China's Rural Homestead the implementation of free use, for the land exceed the standard problem had not been solved. In this regard, can use the homestead the implementation of compensation for the use, of course this is not at all sites. We can on the homestead area of $\mathrm{S}$ to develop a standard $\mathrm{A}$ and the highest standard of $\mathrm{B}$, the partial implementation standard less than area of free use, the area is greater than $\mathrm{A}$ and less than B part of the basic charge royalties, but for more than B of partial charge higher price. Through the countryside homestead right of compensation for the use of, the first can coordinate the rural homestead allocation unreasonable; second can promote the value and use of land; the third to improve rural living environment; fourth can promote the transfer of homestead use right[18].

\section{B. scientific formulation of village planning, effective implementation of land consolidation}

To speed up the improvement of rural production and living conditions and overall appearance, the realization of "village neat", to create a good ecological environment and clean living environment, embody the new concept of well-off society, realize the village "overall neatness, wellproportioned, reasonable layout" target. From the current land use and management of the status quo, the approval process of homestead is passive, the building planning consciousness, cause the homestead use random and scattered. To solve these problems, to revitalize the village idle homestead and unused land, strict control of land size, to achieve intensive land use; to carry out scientific selection, scientific design of rural settlements, improve farmer's production and living environment, to achieve clean and tidy village. Do not conform to the planning of housing should have the plan to have the step to move, the old homestead or exceed the standard parts can be reclaimed for agriculture.

\section{C. the scientific implementation of residential land use regulation, the full implementation of the homestead use right registration}

In the process of homestead and the Department in charge of examination and approval, to achieve the "three to", namely: the admissibility of the homestead application, to the field to review whether the applicant is eligible, intends to use the location, area and so on with the planning; land after the approval in accordance with law, to carry out on-the-spot homestead according to the actual situation of approval; farmers residential completed, to the field check whether or not according to the purposes approved area and other requirements, the use of the land. In addition, to the implementation of the rural homestead of regular and irregular inspections, investigate and deal with illegal land use behavior. In the implementation of land use regulation at the same time, we should fully implement the land use right registration system, including the initial registration and registration [19].

\section{ACKNOWLEDGMENT}

This paper is supported by the soft science key project of Zhejiang Province (2012C25085, 2014C25032) and the National College Students' innovation and entrepreneurship training program.

\section{REFERENCES}

[1] Liu Yaguang. A research review of China's rural land problem[J]. Southeast science 2011(02)

[2] Zhang Zhenyong. The study of rural homestead system evolution[D]. Shandong Agricultural University, 2013

[3] Zhou Liqun, Zhang Hongxing. Research on rural land system transition experience: from the "Homestead" to "ticket" exchange [J]. Nanjing social science. 2011 (08)

[4] Diao Qihuai. The problems and the reform direction in system of countryside homestead use right[J] rural economy. 2011(10)

[5] Wang Liuyan. Analysis of conflicts between of the use right of homestead and inheritance right of house[J]. reform and strategy 2011 (10)

[6] Cao Qiang. Research of the rural homestead circulation legal[J]. Special economic zones 2012(01)

[7] Dong Hong. Mechanism of The rural residential land use right transfer market[J]. Search 2011 (03).

[8] Wu Mingfa. Research on transfer mechanism of land use right [D]. Nanjing University of Agricultural 2012

[9] Xue Fengrui. The rural homestead occupied and circulation system innovation [J]. open review. 2014 (01)

[10] Chen Rongqing, Zhang Ming, Chen Hongfei. Empirical analysis of circulation of the rural homestead Based on the perspective of the farmers $[\mathrm{J}]$. Resource and Industry 2011(05).

[11] Song Jinyun. The exit of homestead mechanism in the citizenization mi grant workers[D]. Anhui University,2014

[12] Dai Yanyan. Study of Rural Homestead exit mechanism of Shanghai [J]. Shanghai land and resources. 2012 (01)

[13] He Changhong. Problem and suggestions of management of Homestead[J]. Chinese Land. 2011 (10)

[14] Shen Peng. Thinking of improved rural homestead management[J]. China land 2011 (07)

[15] Wang Jiye. New rural construction and land management [J]. rural economy and science and technology, 201202

[16] Li Manzhi. The transfer of the homestead right of use under real right law $[\mathrm{J}]$. Journal of Guangxi Administrative Institute of politics and law Cadre, 2006, (1).

[17] research center of land administration in Chinese Institute of land surveying and Planning. The problem of China city suburban homestead[J]. Chinese land, 2007, (1).

[18] Zhu Wenliang, Wang Zhongming, Jin long. Reforming the right of homestead use system in the countryside and improving land use efficiency[C]. Twelfth Chinese Association Annual Meeting Proceedings

[19] Yue Ruifeng. The use and management of homestead right of countryside in the construction of new socialist $[\mathrm{J}]$. North China land and resources, 2009 (6) 